\title{
Positive trends in organic carbon storage in Swedish agricultural soils due to unexpected socio-economic drivers
}

\author{
C. Poeplau ${ }^{1}$, M. A. Bolinder ${ }^{1}$, J. Eriksson ${ }^{2}$, M. Lundblad ${ }^{2}$, and T. Kätterer ${ }^{1}$ \\ ${ }^{1}$ Swedish University of Agricultural Sciences (SLU), Department of Ecology, Box 7044, 75007 Uppsala, Sweden \\ ${ }^{2}$ Swedish University of Agricultural Sciences (SLU), Department of Soil and Environment, \\ Box 7014, 75007 Uppsala, Sweden \\ Correspondence to: C. Poeplau (christopher.poeplau@ @lu.se)
}

Received: 29 January 2015 - Published in Biogeosciences Discuss.: 3 March 2015

Revised: 8 May 2015 - Accepted: 11 May 2015 - Published: 3 June 2015

\begin{abstract}
Soil organic carbon (SOC) plays a crucial role in the global carbon cycle as a potential sink or source. Land management influences SOC storage, so the European Parliament decided in 2013 that changes in carbon stocks within a certain land use type, including arable land, must be reported by all member countries in their national inventory reports for greenhouse gas emissions. Here we show the temporal dynamics of SOC during the past 2 decades in Swedish agricultural soils, based on soil inventories conducted in 19881997 (Inventory I), 2001-2007 (Inventory II) and from 2010 onwards (Inventory III), and link SOC changes with trends in agricultural management. From Inventory I to Inventory II, SOC increased in 16 out of 21 Swedish counties, while from Inventory I to Inventory III it increased in 18 out of 21 counties. Mean topsoil $(0-20 \mathrm{~cm})$ SOC concentration for the entire country increased from 2.48 to $2.67 \% \mathrm{C}$ (a relative increase of $7.7 \%$, or $0.38 \% \mathrm{yr}^{-1}$ ) over the whole period. We attributed this to a substantial increase in ley as a proportion of total agricultural area in all counties. The horse population in Sweden has more than doubled since 1981 and was identified as the main driver for this management change $\left(R^{2}=0.72\right)$. Due to subsidies introduced in the early 1990s, the area of long-term set-aside (mostly old leys) also contributed to the increase in area of ley. The carbon sink function of Swedish agricultural soils demonstrated in this study differs from trends found in neighbouring countries. This indicates that country-specific or local socio-economic drivers for land management must be accounted for in larger-scale predictions.
\end{abstract}

\section{Introduction}

The size of the global soil carbon pool exceeds that of the atmosphere and terrestrial vegetation combined (Lal, 2004). Land use and land management significantly affect the balance between soil carbon inputs and outputs. Agriculture has been identified as the most intensive form of land use, both as regards the fraction of net primary production exported annually (Haberl et al., 2007) and the intensity of mechanical soil disturbance by tillage, which may increase carbon output (Baker et al., 2007). Agriculture therefore plays a crucial role with respect to the global carbon cycle and the concentration of atmospheric $\mathrm{CO}_{2}$ (Houghton et al., 1999). All countries complying with Annex I of the United Nations Framework Convention on Climate Change (UNFCCC) are obliged to report their annual carbon emissions in national inventory reports (NIRs). The $\mathrm{CO}_{2}$ fluxes from the soil are usually estimated as the net change in soil organic carbon (SOC) stocks. However, annual changes in SOC are difficult to quantify in the short term $(<10$ years) and can also be costly to measure on a national scale. Thus, each country has to find solutions for estimating and reporting SOC changes according to their needs and the financial resources available for the task. Many countries estimate SOC changes after land use change using default methods (Tier 1) described in the IPCC guidelines on national greenhouse gas inventories (IPCC, 2006). To date, accounting for SOC changes within arable soils has been voluntary. Major trends in SOC due to changes in agricultural land management, e.g. in fertilisation, ploughing depth, residue management, crop rotation or crop type, are therefore overlooked. However, it has been shown 
that land management changes can have significant effects on soil carbon (Kätterer et al., 2012, 2014; Sleutel et al., 2003). Socio-economic drivers, such as the current demand for bioenergy crops, can lead to drastic and rapid changes in land management. In 2013, the European Parliament therefore decided that member states of the European Union must include arable land and grazing land management in their inventory reports (Anonymous, 2013a). Sweden is one of the countries reporting annual soil carbon changes in agricultural soils within the land use, land use change and forestry (LULUCF) sector according to an IPCC Tier 3 method. This is done by means of the introductory carbon balance model (ICBM), which has been calibrated on long-term field experiments (Andrén and Kätterer, 1997; Andrén et al., 2004). The approach uses national statistics on the proportion of agricultural land within different cropping and animal production systems, together with data on net primary productivity reflecting temporal changes in management practices. In addition, the Swedish Environmental Protection Agency (SEPA) has long had a national soil monitoring programme, with SOC as one of the parameters included. The first inventory was conducted during 1988-1997 and this database was used in the initialisation calculations with the ICBM model (Andrén et al., 2008). In the inventory, the SOC content at 3146 sampling locations was determined. Now, two more inventories (2001-2007; from 2010 onwards) have been conducted, providing a solid base for evaluating the temporal dynamics of SOC in Swedish agricultural soils. Similar work is being carried out for agricultural soils in the neighbouring countries of Finland and Norway (Heikkinen et al., 2013; Riley and Bakkegard, 2006), as well as in England and Wales, Belgium and the Netherlands (Bellamy et al., 2005; Reijneveld et al., 2009; Sleutel et al., 2003). In the Netherlands, a slight increase in SOC was observed between 1984 and 2004, but could not be clearly attributed to specific land use, climate or management changes. In all other countries, a significant decline in SOC was detected for the past 3-4 decades and was attributed to increasing decomposition of SOC due to global warming or to changes in management. In recent decades, the Swedish agriculture sector has undergone a number of changes, with loss of total agricultural area accompanied by increasing imports of agricultural products, decreased milk and meat production and increased organic farming being indicators of ongoing extensification (official statistics of the Swedish Board of Agriculture, downloaded from http://statistik.sjv.se). The aim of the present study was to assess the temporal dynamics of SOC in Swedish agricultural land based on the results currently available from the ongoing soil monitoring programme and to evaluate the potential relationships with changes in management or climate reflected in national statistics.

\section{Materials and methods}

\subsection{The soil carbon data sets}

In the soil monitoring programme initiated by SEPA, agricultural soils are sampled in the depth intervals of $0-20 \mathrm{~cm}$ (topsoil), representing the plough layer, and 40-60 cm (subsoil; Eriksson et al., 1997). Within a radius of $5 \mathrm{~m}$ around the specified sampling coordinate, nine core samples are taken and pooled to a composite sample. Fresh samples are sent to the laboratory for air-drying. The air-dry samples are passed through a $2 \mathrm{~mm}$ sieve and later analysed for $\mathrm{pH}\left(\mathrm{H}_{2} \mathrm{O}\right)$, total carbon, nitrogen and sulfur content, base cations, phosphorus, soil texture (only in Inventory I) and different trace elements. To date, only the topsoil samples have been analysed, while the subsoil samples are in storage. Samples with $\mathrm{pH}\left(\mathrm{H}_{2} \mathrm{O}\right)$ exceeding 6.7 are treated with $2 \mathrm{M} \mathrm{HCl}$ to remove carbonates and repeatedly analysed for organic carbon content. The dry weight of each sample is determined by drying a subsample at $105^{\circ} \mathrm{C}$. Carbon concentrations reported in this study are thus on a soil dry weight basis. As mentioned above, three inventories have been conducted to date, the first (Inventory I) in 1988-1997, the second (Inventory II) in 2001-2007 and the third (Inventory III) from 2010 onwards. Due to strategic considerations within the monitoring programme and budgetary constraints, Inventories I-III differ in terms of number of sampling points and partly also location of the sampling plots. Inventory I includes 3146 sampling points, whereas Inventory II only comprises 2034 sampling points. In addition, the fields from which the samples were taken are not the same for these two inventories. Inventory III was initiated as a resampling of the 2034 locations in Inventory II and is still ongoing. Within Inventory III, a total of 1113 locations have been resampled to date, but the last results are not likely to be available before 2018. An indepth investigation of SOC dynamics between Inventories II and III in relation to sampling location is therefore not included in this study. Due to use of a stratified sampling grid, it can be assumed that a representative part of the agricultural area in Sweden has been resampled so far in Inventory III. In the most northern counties the resampling was completed in 2014, irrespective of the sampling year in Inventory II, leading to slightly higher data coverage there than in other Swedish counties (Table 1). All soils with a SOC content exceeding $7 \%$ are classified as organic soils (Andrén et al., 2008) and excluded from analysis due to the fact that $C$ losses or gains in organic soils cannot be accounted for by simply measuring the SOC concentration at a certain soil depth. To detect changes in organic soils, the height of the organic layer has to be monitored over time, which is not done in the SEPA inventories. The total amount of mineral soil samples available for the present study were 2923, 1878 and 932, for Inventory I, II and III, respectively. Soil carbon concentrations of all inventories were measured in the same laboratory by dry combustion with an elemental analyser (LECO, 
St Joseph, MI, USA). For quality control and to exclude measurement bias, a subsample of a soil from Inventory I has been analysed repeatedly at regular intervals over the years. The Inventory I-III data sets are similar regarding their distribution into different 'size classes' of SOC concentration, as can be seen in Fig. 1. Potential shifts in regional average SOC concentrations are thus not biased by e.g. relative overrepresentation of a certain size class. We deemed it appropriate to use regional mean values of SOC as the only way to evaluate temporal SOC dynamics over all three inventories. To assess the dynamics of the average regional SOC content over time and link those to certain drivers, we used county as the spatial unit with the highest resolution of management data. A list of the 21 counties in Sweden and the agricultural area represented by one sampling point (mineral soil) is presented in Table 1. To check whether the counties are equally represented in the county averages, we divided the number of points in each county by the agricultural area. The temporal trends in agricultural area were thereby taken into account. In Inventory I, II and III, each sampling point represented an average area of $918 \pm 89,1468 \pm 233$ and $2845 \pm 1034$ ha, respectively. The large standard deviation in Inventory III can be attributed to the low coverage of the counties Gotland and Blekinge, where only 17 (out of 54) and 5 (out of 20) points, respectively, have been resampled to date (Table 1). Carbon dynamics findings for these two counties, at least when considering Inventory III, have thus to be interpreted with caution. Apart from those counties, sampling points were rather equally distributed across the agricultural land in Sweden, which was achieved using a random starting point and then a fixed grid related to that point. The observed variance can primarily be explained by the differing abundance of organic soils, which were excluded a posteriori, among the counties. Furthermore, for various reasons, such as land use change, several sampling points could not be resampled in Inventory III. The management history or the current crop at each sampling point was not reported during sampling.

\subsection{Management and climate data}

In the present study, we used national agricultural statistics to derive different explanatory variables and evaluated them against the regional trends in SOC. The statistics were downloaded from the website of the Swedish Board of Agriculture (http://statistik.sjv.se). The regional units in which Swedish agricultural statistics are available are production regions $(n=8)$ and counties (currently $n=21$; Fig. 2, Table 1). In order to use the highest spatial resolution possible, we decided to compute statistics at county level. For each year since 1981, we compiled county-wise data for the whole country on the total area on which a certain crop type has been grown (20 different crops), expressed as proportion of total agricultural area. We also compiled data on total number of animals and animal categories in agriculture. As a rough characterisation of agricultural production in each
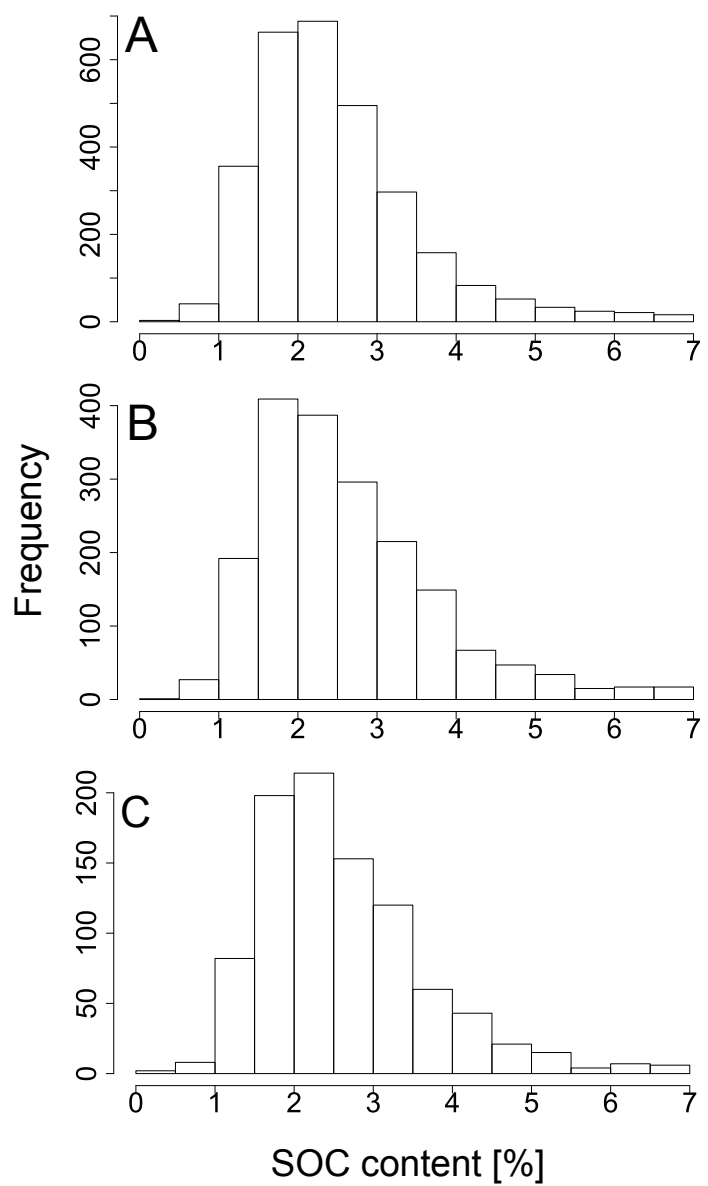

Figure 1. Histogram of measured carbon concentration $(0.5 \% \mathrm{C}$ increments) for (a) Inventory I, (b) Inventory II and (c) Inventory III.

county and an overview over Swedish agriculture, we summarised the 20 different crops into three categories: (i) cereals, (ii) perennial crops and (iii) root crops, oilseed crops and other crops, and plotted their areal frequency (Fig. 3). Total area of fallow land was divided into green fallow and uncultivated fallow using a fixed ratio of 2.45 as a mean value of reported proportions over time and for different Swedish production regions (Thord Karlsson, personal communication, 2015). Green fallow is defined as long-term (3 years or more) set-aside land that mostly consists of old leys, while uncultivated fallow is usually short-term ( 1 to 2 years) setaside land which is defined as arable land with the stubble left in the field after harvest and weeds growing. The proportion of land under cover crops is reported in statistics only for the eight different agricultural production regions of Sweden instead of counties, and only for the last 6 years (Helena Aronsson, SLU, personal communication, 2014). We averaged those 6 years and assigned the counties to the different regions as best possible.

The number of animals in each category was used to estimate total annual manure mass $\left[\mathrm{Mg} \mathrm{ha}^{-1}\right]$ produced in 
Table 1. List of Swedish counties and their average agricultural area since the start of the inventories (1988), total number of sampling points used in Inventories (Inv.) I, II and III and the coverage of one sampling point in each inventory.

\begin{tabular}{|c|c|c|c|c|c|c|c|c|}
\hline \multirow[b]{2}{*}{ Code } & \multirow[b]{2}{*}{ County } & \multirow{2}{*}{$\begin{array}{r}\text { Agricultural } \\
\text { area [kha] }\end{array}$} & \multicolumn{3}{|c|}{$\begin{array}{c}\text { Total number of } \\
\text { sampling points in: }\end{array}$} & \multicolumn{3}{|c|}{$\begin{array}{l}\text { Coverage of one } \\
\text { point [thousand ha] }\end{array}$} \\
\hline & & & Inv. I & Inv. II & Inv. III & Inv. I & Inv. II & Inv. III \\
\hline 1 & Stockholm & 88 & 94 & 68 & 34 & 0.98 & 1.28 & 2.43 \\
\hline 3 & Uppsala & 157 & 178 & 107 & 55 & 0.86 & 1.41 & 3.02 \\
\hline 4 & Södermanland & 130 & 148 & 87 & 42 & 0.91 & 1.50 & 3.00 \\
\hline 5 & Östergötland & 208 & 205 & 154 & 74 & 1.03 & 1.36 & 2.73 \\
\hline 6 & Jönköping & 91 & 111 & 64 & 30 & 0.83 & 1.45 & 2.93 \\
\hline 7 & Kronoberg & 51 & 56 & 36 & 16 & 0.99 & 1.43 & 2.96 \\
\hline 8 & Kalmar & 126 & 147 & 86 & 46 & 0.89 & 1.48 & 2.64 \\
\hline 9 & Gotland & 85 & 82 & 54 & 17 & 1.02 & 1.60 & 5.03 \\
\hline 10 & Blekinge & 33 & 43 & 20 & 5 & 0.83 & 1.67 & 6.21 \\
\hline 12 & Skåne & 454 & 548 & 310 & 142 & 0.84 & 1.48 & 3.13 \\
\hline 13 & Halland & 115 & 133 & 79 & 33 & 0.91 & 1.47 & 3.32 \\
\hline 14 & Västra Götaland & 477 & 479 & 376 & 180 & 1.01 & 1.28 & 2.60 \\
\hline 17 & Värmlands & 110 & 123 & 73 & 32 & 0.90 & 1.52 & 3.34 \\
\hline 18 & Örebro & 108 & 109 & 79 & 37 & 1.02 & 1.36 & 2.83 \\
\hline 19 & Västmanland & 117 & 109 & 77 & 32 & 1.14 & 1.61 & 3.17 \\
\hline 20 & Dalarna & 61 & 62 & 39 & 18 & 1.01 & 1.57 & 3.35 \\
\hline 21 & Gävleborg & 71 & 74 & 47 & 41 & 1.01 & 1.52 & 1.64 \\
\hline 22 & Västernorrland & 53 & 64 & 33 & 30 & 0.90 & 1.58 & 1.63 \\
\hline 23 & Jämtland & 42 & 45 & 23 & 21 & 0.99 & 1.85 & 1.92 \\
\hline 24 & Västerbotten & 73 & 69 & 48 & 33 & 1.13 & 1.49 & 2.11 \\
\hline 25 & Norrbotten & 38 & 43 & 16 & 13 & 1.00 & 2.39 & 2.61 \\
\hline
\end{tabular}
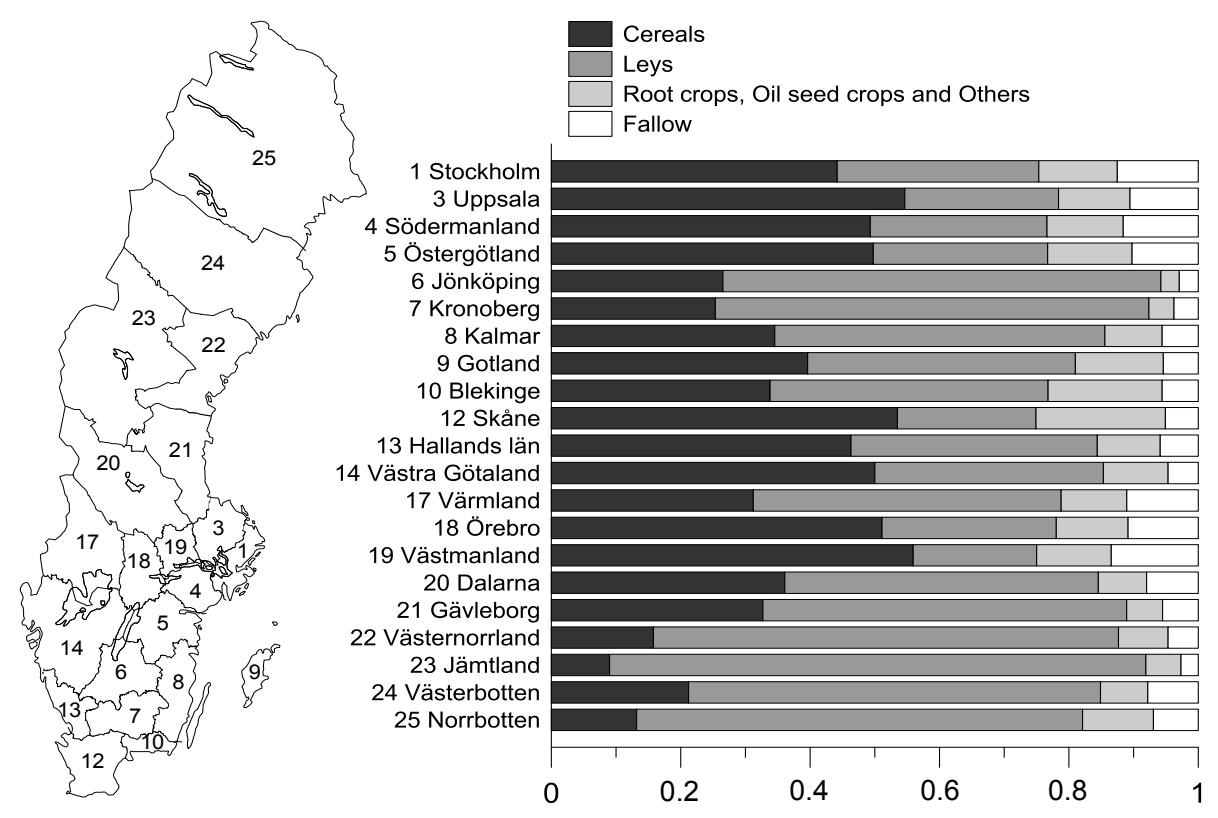

Figure 2. (Left) Map of Sweden showing the current division into counties, numbered according to the codes listed in Table 1. (Right) Relative proportions of different crops grown on the agricultural area in each county, averaged for the period 1988-2013.

each county by applying coefficients published in a guideline report on manuring by the Swedish Board of Agriculture (Anonymous, 2015). These coefficients were also used in a model called STANK in MIND, which is the official model for input/output accounting on farm level in Sweden and is used in the Swedish National Inventory Report for greenhouse gas emissions under the framework of UNFCCC (Swedish Environmental Protection Agency, 2013). 


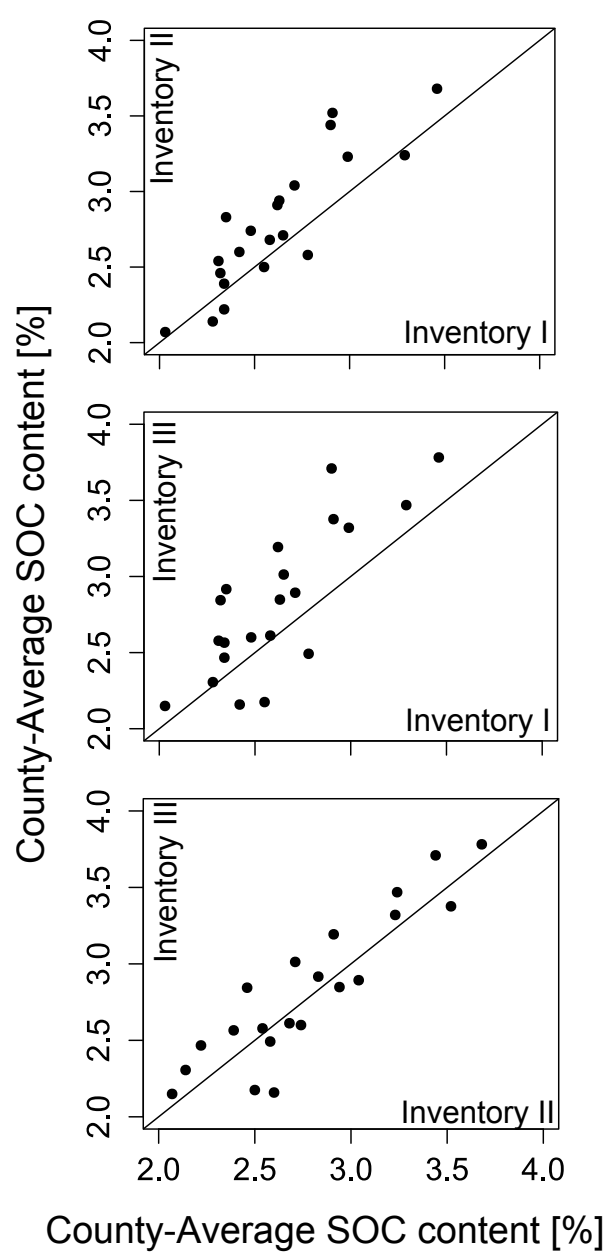

Figure 3. County-average carbon concentrations from Inventories I-III plotted against each other, with $1: 1$ line to visualise shifts in carbon concentration.

A large proportion of Swedish horses are not reported in the statistics, since they are associated with holdings smaller than 2 ha, which are not included in the official agricultural statistics. To date, only two specific horse surveys have been conducted in Sweden, by Statistics Sweden (SCB) in 2004 and 2010 (Anonymous, 2005, 2011). In both surveys, the total number of horses and the number of horses in agriculture are given for each county. The number of horses in agriculture exactly matched the value in the animal statistics published by the Swedish Board of Agriculture and accounted for less than one-third of the total number of horses in Sweden. In the present study, the county-specific ratios (horses in agriculture/total horses) in 2004 and 2010 were averaged and applied to all other years in the agricultural statistics to obtain an estimate of the temporal change in total number of horses in Sweden from 1981 to 2013. However, only horses in agriculture were considered in the manure statistics, based on the assumption that manure from non-agricultural horses would not find its way to fields on farms larger than two hectares.
Daily climate data from 1980-2009 (to create 30-year averages) across Sweden were obtained from 23 different weather stations managed by the Swedish Meteorological and Hydrological Institute (SMHI). These stations were initially selected to cover all agricultural land in Sweden and were linked to the eight production regions, but were not perfectly equally distributed over all counties. Eleven of the 21 counties were associated with one climate station, six counties had two (values from which were averaged) and four counties had none. For those counties which had no climate station, we used average climate data for their neighbouring counties to the north and south.

\subsection{Statistics}

To assess the potential impact of different variables on SOC concentrations, we correlated management and climate variables averaged over the whole period 1988-2013 to average SOC concentration (Inventories I-III) per county. We used the Spearman's Rho Test to assess the significance of the correlations. The explanatory variables used were: proportion of a certain crop to total agricultural area, total manure production, soil $\mathrm{pH}$, soil texture, mean annual temperature (MAT) and mean annual precipitation (MAP). For $\mathrm{pH}$ and soil texture we used county-averaged measured values from the Inventories. To test the hypothesis that the change in SOC concentration between two inventories for all of Sweden differs from zero, we calculated differences in arithmetic county means between two inventories and tested them against zero in a weighted one-sample Student's $t$-test. As a weighting factor we used the amount of sampling locations in each county (in Inventory I) to account for the different size and agricultural area of each county. A normal distribution was obtained for all three cases (Inventory I vs. II, I vs. III and II vs. III). Temporal changes in SOC and as changes in management and climate over time were expressed as response ratio $(\mathrm{RR})$ :

$\mathrm{RR}_{\mathrm{V}}=V_{2013} / V_{\text {year }}$,

where $V_{2013}$ is the magnitude of an explanatory variable in 2013 and $V_{\text {year }}$ that of the same variable in a previous year, 1991 in most cases, which was the year with the highest data coverage of all years considered in the approximate centre of the period 1988-1997 (sampling period for Inventory I). The area of ley was not reported for the years 1992-1995, so a robust average of the whole period in Inventory I would have biased the RR values of this variable. For the management variables of the counties Skåne and Västra Götaland, we used the years 1997 and 1998, respectively, as reference years, since both counties were founded only in these years. Thus, the total time span of all management variables (excluding Skåne and Västra Götaland) was 22 years. Those ratios, as well as the mean predictors mentioned in the previous section and the starting carbon concentrations $\left(\mathrm{SOC}_{\text {Start }}\right)$, were used in maximum likelihood estimations to fit robust multi- 
ple linear regressions explaining the variability of observed changes in SOC $\left(\mathrm{RR}_{\mathrm{SOC}}\right)$ between counties. Robust regressions are not overly affected by the violation of assumptions such as heteroscedasticity and slight non-normal distributions of the variables or single outlying data points, and are therefore an advantage when combining variables with differing dimensions (Andersen, 2008). We used $p=0.05$ as the significance limit in all tests. All analyses were performed using the R software.

\section{Results and discussion}

\subsection{Effect of management and climate on average soil carbon concentrations}

Among all crops grown, only the proportion of leys (including green fallow) was able to explain a significant part of the variation in average carbon concentration between counties ( $R=0.64$; Table 2$)$. The average SOC concentration was found to be highest in the counties with the highest proportion of leys grown (Fig. 2). This might be explicable by the fact that leys produce much more belowground biomass and exudates than most other crops (Bolinder et al., 2007b). For example, a review by Bolinder et al. (2012) found an average belowground biomass of $7.8 \mathrm{Mg} \mathrm{ha}^{-1}$ for perennial forage crops, compared with only $2 \mathrm{Mg} \mathrm{ha}^{-1}$ for small-grain cereals. Roots and their exudates are known to contribute more to the stable soil carbon pool than aboveground plant material (Kätterer et al., 2011; Rasse et al., 2005). It is also well known that ley-based crop rotations are less susceptible to SOC losses through erosion, because of the permanent surface cover. Indeed, numerous studies have reported higher SOC concentrations under grassland soils compared with arable soils, despite similar aboveground net primary productivity (Bolinder et al., 2012; Leifeld and KögelKnabner, 2005; Poeplau and Don, 2013). A recent review of SOC stocks under Nordic conditions (Kätterer et al., 2013) showed that on average $0.52 \mathrm{Mg} \mathrm{ha}^{-1} \mathrm{yr}^{-1}$ more carbon was retained in soils in ley-arable systems than in exclusively annual cropping systems (mostly cereals). In the present study, the average areal application rate of manure by county, which was directly derived from the number of animals, was also positively correlated to SOC concentration. Farmyard manure has been shown to be among the most effective organic amendments for carbon sequestration in soils (Kätterer et al., 2012; Smith et al., 2005), so this positive correlation is reasonable. There was a tendency for a negative correlation between MAT and SOC concentration, but this was not significant. A colder climate usually leads to decreased soil biological activity and thus decreased SOC decomposition (Bolinder et al., 2007a). However, lower C inputs as a result of lower net primary production are likely to compensate for much of the difference in decomposition. Finally, we found that soil $\mathrm{pH}$ was a strong predictor of soil carbon content.
Table 2. Correlation matrix showing rank correlation coefficient $(R$ value) for the different predictors of SOC in each county (averaged over Inventories I-III), with \pm indicating the direction of the correlation. The selected predictors were: average mass of manure produced and potential application rate $\left[\mathrm{Mg} \mathrm{ha}^{-1} \mathrm{yr}^{-1}\right]$, ley as a proportion of total agricultural area [\%], the condensed climate variable $r_{\mathrm{e}}$ and average soil $\mathrm{pH}$. MAT $=$ mean annual temperature.

\begin{tabular}{lrrrr}
\hline & Ley & MAT & $\mathrm{pH}$ & SOC \\
\hline Manure & $0.51(+)$ & $\mathrm{ns}$ & $\mathrm{ns}$ & $0.53(+)$ \\
Ley & & $0.61(-)$ & $0.66(-)$ & $0.64(+)$ \\
MAT & & & $\mathrm{ns}$ & $\mathrm{ns}$ \\
pH & & & & $0.56(-)$ \\
\hline
\end{tabular}

However, all predictors were intercorrelated, and comparisons are not straightforward (Table 2). Agricultural management is always adapted to climate. In colder regions, mostly in the northern counties of Sweden, the proportion of ley is higher than in milder southern parts, because the short northern growing season and low growing season temperature sum exclude the production of typical cash crops (Bolinder et al., 2010). In Jämtland, Västerbotten and Norrbotten, the most northerly counties of Sweden, ley as a proportion (averaged over the past 2 decades) of total agricultural area was 78, 62 and $67 \%$, respectively (Fig. 2). Consequently, farms in the north tend to specialise in livestock farming, which in turn leads to higher manure application to fields. Liming is probably carried out more regularly in highly productive regions (southern Sweden), where the proportion of ley is lower, which might explain the negative correlation between $\mathrm{pH}$ and soil carbon content. In addition to that, calcareous bedrock leads to high $\mathrm{pH}$ values in certain parts of southern Sweden. However, soil biological activity, and thus carbon decomposition, decreases with decreasing soil $\mathrm{pH}$, further indicating that a direct link between soil $\mathrm{pH}$ and soil carbon is also possible. A negative effect of perennial grasses on soil $\mathrm{pH}$ due to a strong base cation consumption has also been found (McIntosh and Allen, 1993), which might explain the strong negative correlation between $\mathrm{pH}$ and proportion of ley. Since management is adapted to climate and affects both abiotic and biotic soil properties, this highlights the relevant and difficult question of whether management or abiotic conditions are the most important driver of SOC dynamics. However, the data sets used here indicate that even at the national scale, changes over time in the proportion of leys, manure application, soil $\mathrm{pH}$ and possibly climate can be used as potential predictors of changes in SOC.

\subsection{Temporal dynamics of soil organic carbon and its causes}

The average county-scale SOC concentration significantly increased between Inventory I and Inventory II $(p<0.001)$ in 16 out of 21 counties (Fig. 3a). This positive trend con- 


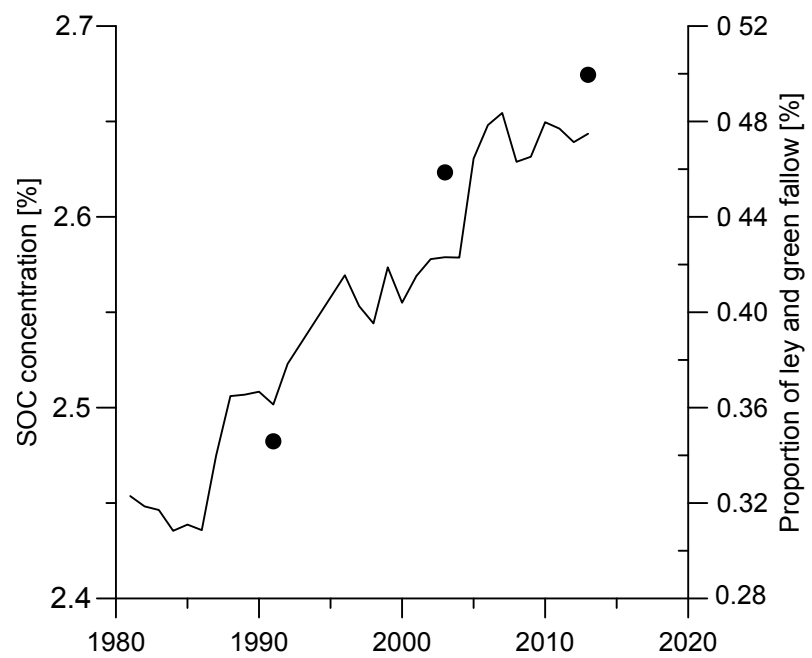

Figure 4. Country-average carbon concentrations for Inventories IIII and trends in ley and green fallow as a proportion of total agricultural area.

tinued between Inventories II and III, with the SOC concentration increasing in 13 out of 21 counties $(p<0.001)$. Finally, between Inventory I and III, representing the longest period of observations, SOC concentration increased in 18 out of 21 counties (Fig. 3b, $p<0.001$ ). The country-average SOC concentration increased from 2.48 to $2.67 \%$ during the whole period (Fig. 4), which constitutes a relative increase of 7.7 , or $0.38 \% \mathrm{yr}^{-1}$. This provides evidence that Swedish agricultural soils have indeed acted as a net carbon sink over the past 2 decades. This is in contrast to the trends observed in neighbouring countries, e.g. for Finland Heikkinen et al. (2013) reported a net SOC loss of $0.2-0.4 \% \mathrm{yr}^{-1}$ from the period 1974-2009. They attributed this loss partly to a shift in agricultural management and farming structure, with less perennial ley in the rotation and more monoculture in recent years. Severe losses of SOC from agricultural soils have also been observed in Southeast Norway and have been attributed to land drainage, climate change and changes in the rotation (Riley and Bakkegard, 2006). In Belgium, Sleutel et al. (2003) identified the 'Manure Action Plan' introduced by the Belgian government, which placed restrictions on the excessive use of manure, as the major cause of declining SOC stocks in that country. However, Bellamy et al. (2005) claimed that climate change was the driver for soils in England and Wales acting as a carbon source over recent decades. Consequently, SOC in agricultural soils on a national scale has shown to be mainly sensitive to changes in the presence of ley in the rotations, the amount of manure applied and climate conditions. All these factors were also tested as predominant predictors of SOC concentration in the present study.

The data showed that the proportion of ley in Swedish agriculture has increased steadily since 1981, the earliest year investigated in this study (Fig. 4). In all counties, ley has become more abundant over time, with increases ranging from $24 \%$ in Norrbotten to $96 \%$ in Stockholm county. In $2013,47 \%$ of the agricultural area in Sweden was used for ley and green fallow, whereas in 1981 it was only $32 \%$ (Fig. 4). In the same period, the average amount of manure applied to soils in Sweden decreased by 5\% (1981-2013) or remained stable $(+1 \%, 1991-2013)$, presumably because of the decreasing numbers of cattle and pigs. During recent decades, meat imports have become more important in Sweden (Cederberg et al., 2009). Therefore, the observed positive trend in soil carbon cannot be explained by recent trends in manure production and application rates to soil. Furthermore, averaged over the 22 SMHI stations, the climate conditions did not change within the study period. Soil $\mathrm{pH}$ increased by only $1.7 \%$ as an average for all counties and is thus unlikely to be of any relevance for the trend in SOC. The most likely explanation for the increasing trend observed for SOC is thus the increase in ley. When using the pedotransfer function reported by Kätterer et al. (2006) to estimate bulk density, the average SOC stock in the first Inventory was $66 \mathrm{MgCha}^{-1}$ in $0-20 \mathrm{~cm}$ soil depth. The found annual increase of $0.38 \%$ would thus correspond to $0.25 \mathrm{Mg} \mathrm{Cha}^{-1}$. The proportion of ley and green fallow increased between 1991 and 2013 by $33 \%$, so the expected change in SOC stock would be $0.17 \mathrm{MgCha}^{-1}$, when the reported accumulation rate of Kätterer et al. (2013; $\left.0.52 \mathrm{Mg} \mathrm{ha}^{-1}\right)$ is considered. Conant et al. (2001) reported an annual increase in SOC stock of $1 \mathrm{Mg} \mathrm{Cha}^{-1}$ after cropland to grassland conversion, which would account for $0.33 \mathrm{MgC} \mathrm{ha}^{-1}$. The calculated accumulation of $0.25 \mathrm{Mg} \mathrm{Cha}^{-1}$ is the exact mean of those two estimates. Furthermore, Heikkinen et al. (2013) report an annual decrease in SOC of $0.4 \%$, which equals the annual increase of $0.38 \%$ found in our study. As the first reason for this decline, they mention significant changes from permanent grasslands and perennial crops to cultivation of annual crops. We conclude that attributing the increase in SOC to the increase in ley and green fallow area is reasonable.

Having identified ley as a major predictor, we tested this by correlating the change in SOC in each county over the whole period $\left(\mathrm{RR}_{\mathrm{SOC}}\right)$ to the change in ley area in each county $\left(R_{\text {Ley }}\right)$. We found a weak, non-significant positive correlation $(R=0.31)$ between the two, indicating that higher SOC accumulations occurred in counties with strong increases in the proportion of ley. We then applied several different explanatory variables in a robust linear regression model in an attempt to explain more of the observed variation in SOC concentration across counties. The best model fit explained $41 \%$ (adjusted $R^{2}=0.41$ ) of the variance and consisted of: $\mathrm{RR}_{\text {Ley }}+\mathrm{RR}_{\text {Manure }}+\mathrm{SOC}_{\text {Start }}-$ Organic farming area (Fig. 5), in which all four variables were significant. The positive response of soil carbon to the increase in the proportion of ley was thus less pronounced in counties where the strongest decreases in manure production occurred, which is reasonable. The variables $R_{\text {Manure }}$ and $\mathrm{RR}_{\text {Ley }}$ were not correlated. The negative effect of the propor- 


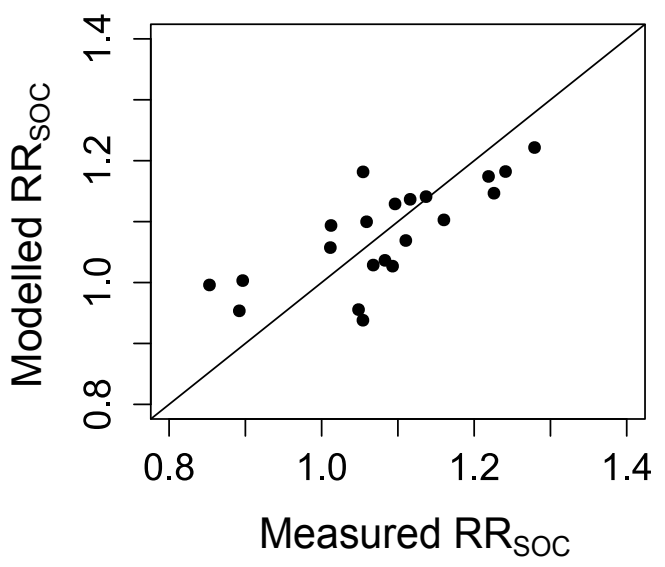

Figure 5. Measured versus modelled county-average carbon concentration changes $\left(\mathrm{RR}_{\mathrm{SOC}}\right)$ with model equation: $\mathrm{RR}_{\text {SOC }}=-0.04+0.29 \times \mathrm{RR}_{\text {Ley }}+0.38 \times \mathrm{RR}_{\text {Manure }}+0.17 \times \mathrm{C}_{\text {Start }}-$ $0.8 \times$ Organic farming area.

tion of organic farming could be explained by the fact that since it bans the use of mineral fertilisers, it generally leads to a reduction in yield (Kirchmann et al., 2008) and thus to lower carbon inputs to the soil (Leifeld et al., 2013). Furthermore, Ammann et al. (2007) showed that nitrogen deficiency can lead to increased decomposition of the existing soil carbon pool. The increase in organic farming in the past decade may therefore explain why the response of soil carbon to an increasing proportion of ley was weaker between Inventory II and III than between Inventory I and II (Fig. 4). The average starting concentration of SOC $\left(\mathrm{SOC}_{\text {Start }}\right)$ as a predictor of the response of SOC to an increase in ley is not easy to understand, but it was the most powerful explanatory variable, leading to significance of all other variables considered even without being correlated to $\mathrm{RR}_{\mathrm{SOC}}$ as such. A link to soil texture, with e.g. the highest starting carbon concentration and the highest accumulation of carbon in fine-textured soils, was not found. A weak positive, but not significant, correlation $(R=0.33)$ was found between the change in soil carbon and the proportion of agricultural area under cover crops. This confirms recent findings by Poeplau and Don (2015) that cover crops can be an efficient measure to increase SOC. In the southern counties of Sweden, where cover crops were introduced in 2001 to prevent nitrate leaching during humid autumns, up to $17 \%$ of the total agricultural area was cultivated with cover crops during the period 2007-2013. However, including cover crops as an explanatory variable did not increase the predictive power of the multiple regression model in this study.

\subsection{Socio-economic drivers for the observed land management change}

Ley is primarily used as animal feed, especially for cattle and horses. Therefore the increase in the proportion of ley seems to run contrary to the decrease in cattle numbers in Sweden since $1981(-23 \%)$ and $1991(-11 \%)$. However, the number of horses has more than doubled since $1981(+124 \%)$, and has increased by $48 \%$ since 1991 . At present, the estimated number of horses in Sweden is 370000 , while it was only 165000 in 1981. A horse with normal activity (1 h of daily activity) needs $8 \mathrm{~kg}$ hay or silage and $1.5 \mathrm{~kg}$ oats per day (Anonymous, 2013b). With the average ley yield of 2013,1 hectare of ley could feed 1.06 horses for a year. Thus $30 \%$ of the ley area and $13 \%$ of the total agricultural area in 2013 were used for horses alone. The increase in ley area (288000 ha) is in fact of the same order of magnitude as the estimated increase in horses (205 000). Considering the area and yield statistics against the need for forage for the official number of animals in agriculture in Sweden, it has been estimated that there is overproduction of ley corresponding to 200-300 $000 \mathrm{ha} \mathrm{yr}^{-1}$ (Anonymous, 2008). This is perfectly explained by the number of horses not included in the agricultural statistics (those kept on holdings of $<2 \mathrm{ha}$ ) and thus not included in the calculations by Anonymous (2008). More than two-thirds of the 370000 horses in Sweden are not kept on officially recognised farm holdings but on private property, e.g. around urban areas. With increasing wealth, an increasing number of people can afford to keep a horse. The increase in the Swedish horse population was found here to be highly correlated with the increase in ley per county, with Stockholm, the wealthiest county, having the highest rise in both $\left(R^{2}=0.72\right.$; Fig. 6$)$. This correlation provides evidence that horses may be the most important driver for the increase in the proportion of ley in total Swedish agriculture. While farmers may not own most of these horses, they can sell hay at a good profit to (often wealthy) horse owners, leading to increased interest among farmers in producing hay. The Swedish predilection for owing horses may thus have contributed significantly to the observed increasing trend in SOC, indicating a link between national/regional/local socioeconomic trends and soil carbon sequestration. The amount of fallow land, particularly green fallow, has also contributed to the temporal changes in leys. This type of land use is dependent on farm subsidies in member countries of the European Union (EU). For example, because the clause on 'obligatory' fallow in the EU was removed in 2007, by 2008 the total area of fallow in Sweden declined drastically (by $33 \%$ ) to 134000 ha, its lowest level since 1994, the year before Sweden became a member of the EU. In the intermediate years, green fallow had increased from about 100000 ha in 1995 to a little more than 200000 ha in 2007 (Anonymous, 2008). A certain proportion of the ley increase could also be explained by the increase in organic farming during the last 10 years, when many conventional farms switched their production to organic farming. The proportion of total agricultural area used for organic farming was literally non-existent in the beginning of the 1980s, but by the end of the 1990s had increased strongly due to subsidies. This increase was most pronounced during the period between Inventory II and III, 


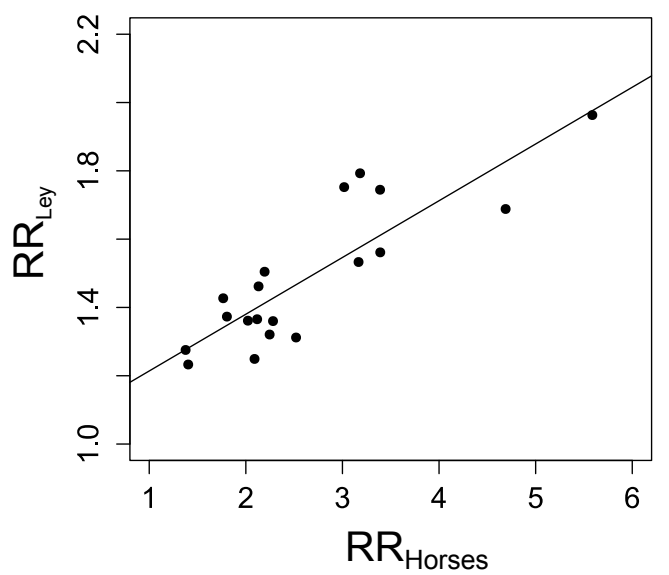

Figure 6. Change in ley as a proportion of total agricultural area $\left(R R_{\text {Ley }}\right)$ as a function of the increase in horse population ( $R R_{\text {Horses }}$ ) for each Swedish county, 1981-2013.

where the areal share of organic farming increased from 6.9 in 2005 to $16.5 \%$ in 2013 (http://statistik.sjv.se). However, as in many other European countries (Maeder et al., 2002; Olesen et al., 2000), organic farming in Sweden concentrates on milk and beef production (Kirchmann et al., 2014), so the main change occurred in a sector that was already forage based. Thus, although the typical rotation in organic farming includes more ley than in conventional farming (Olesen et al., 2000), the increase in organic farming can only explain a small proportion of the countrywide increase in ley. Poeplau et al. (2011) have shown that land use change from arable to grassland can double the SOC stocks in topsoil and that this sequestration effect can last for more than 100 years, depending on climate and soil texture. Thus, even if the trend for increasing ley area levels off in the near future, the trend for increasing SOC will probably persist for decades. In a global context, the explosion of the Swedish horse population may be exceptional and reflect the wealth of a rich country However, incentives for increasing the area of leys or other perennial crops may also be provided elsewhere, e.g. by substituting annual crops grown for bioenergy by perennials. To cope with a steadily increasing food demand, the potential to increase the proportion of ley in global agriculture is limited. Other options, such as cover crop cultivation, might be more realistic and were shown to have a comparable positive effect on SOC (Poeplau and Don, 2015).

\subsection{Further research}

We did not calculate SOC dynamics in terms of stock changes, since this requires data on bulk density and stoniness, which were not measured in this study, and since the uncertainty introduced by estimating both parameters would have been too large. This most likely did not affect the trends observed, since SOC stock changes when calculated on an equivalent soil mass basis are directly proportional to changes in SOC concentration. Only in cases of severe compactions or heavy erosion would the fixed sampling depth of $20 \mathrm{~cm}$ lead to a certain amount of subsoil added during the resampling. Most Swedish croplands are however ploughed to a depth of at least $23 \mathrm{~cm}$. However, stoniness is an important factor to account for in certain regions of Sweden, and estimates of both bulk density and stoniness in future sampling campaigns would improve determination of the absolute sink strength of Swedish agricultural soils. At this degree of resolution, 2 decades is a fairly short period and it is important to maintain the monitoring programme. A longer period, with potentially higher response ratios for soil carbon and the different drivers, might yield a higher degree of explanation. A striking example of this is the strong correlation for the trends in horse population and ley proportion. When using the response ratio $2013 / 1981$, an $R^{2}$ of 0.72 was found, while when using the response ratio 2013 / 1991, the $R^{2}$ decreased to 0.21 (data not shown). When estimating the total sink strength of Swedish agricultural soils, the subsoil should also be taken into account, especially due to the fact that a large part of the accumulated carbon is most likely root derived. Finally, we are in the process of obtaining gridded temperature and precipitation data from climate models that could better characterise the climatic conditions of each county.

This database will be used in continuous validation of the Swedish national system for reporting quantitative changes in SOC stocks, which uses the ICBM model within the IPCC Tier 3 methodology. In addition to the conventional driving variables currently used in that system, such as the total amount of manure produced and the yield of different crop types, this study indicates that national/regional socioeconomic conditions and trends are important factors contributing to the changes in some of the other variables used. The challenge is to obtain good input data with high temporal and spatial resolution. This study also showed that the introduction of carbon stock changes after management changes in the IPCC reporting scheme is reasonable.

\section{Conclusions}

This study provided firm evidence that Swedish agricultural soils have acted as a net carbon sink over the past 2 decades, which is in contrast to trends in neighbouring countries. This is attributable to a strong increase in ley production in each Swedish county of up to $96 \%$ during the last 3 decades. The main driver for this increase has been the rise in the horse population. These results indicate that not only continentalscale socio-economic drivers, such as the demand for bioenergy crops, but also national- or regional-scale drivers can lead to drastic land management changes with effects on SOC. In post-industrial and wealthy societies in particular, local lifestyle 'fashions' can have strong impacts on land 
management and can play a significant role in large-scale predictions of land management change.

Acknowledgements. We thank Robert Weimer for providing a map of Sweden as divided in counties. The Swedish arable soil monitoring programme is sponsored by the Swedish Environmental Protection Agency.

Edited by: Y. Kuzyakov

\section{References}

Ammann, C., Flechard, C. R., Leifeld, J., Neftel, A., and Fuhrer, J.: The carbon budget of newly established temperate grassland depends on management intensity, Agric. Ecosyst. Environ., 121, 5-20, 2007.

Andersen, R.: Modern methods for robust regression, Sage, 2008.

Andrén, O. and Kätterer, T.: ICBM: the introductory carbon balance model for exploration of soil carbon balances, Ecol. Appl., 7, 1226-1236, 1997.

Andrén, O., Kätterer, T., and Karlsson, T.: ICBM regional model for estimations of dynamics of agricultural soil carbon pools, Nutr. Cycl. Agroecosys., 70, 231-239, 2004.

Andrén, O., Kätterer, T., Karlsson, T., and Eriksson, J.: Soil C balances in Swedish agricultural soils 1990-2004, with preliminary projections, Nutr. Cycl. Agroecosys., 81, 129-144, 2008.

Anonymous: Hästar och anläggningar med häst 2004 - resultat från en intermittent undersökning, Statistiska meddelanden JO 24 SM 0501, Sttistiska Centralbyrån, Stockholm, Sweden, 2005.

Anonymous: Kartläggning av mark som tagits ur produktion, (Inventory of land taken out of production), Jordbruksverket Rapport 2008:7, Jordbruksverket, Jönköping, Sweden, 2008.

Anonymous: Hästar och anläggningar med häst 2010 - resultat från en intermittent undersökning, Statistiska meddelanden JO 24 SM 1101, Statistiska centralbyrån, Stockholm, Sweden, 2011.

Anonymous: Decision No 529/2013/EU of the European Parliament and of the council of 21 May 2013 on accounting rules on greenhouse gas emissions and removals resulting from activities relating to land use, land-use change and forestry and on information concerning actions relating to those activities, Official Journal of the European Union, L165, 81-97, 2013a.

Anonymous: Hästgödsel- en naturlig resurs, Jordbruksinformation 5, Jordbruksverket, Jönköping, Sweden, 2013b.

Anonymous: Riktlinjer för gödsling och kalkning (Guidelines for fertilization and liming), Jordbruksverket, Jönköping, Sweden, 2015.

Baker, J. M., Ochsner, T. E., Venterea, R. T., and Griffis, T. J.: Tillage and soil carbon sequestration - What do we really know?, Agric. Ecosyst. Environ., 118, 1-5, 2007.

Bellamy, P. H., Loveland, P. J., Bradley, R. I., Lark, R. M., and Kirk, G. J.: Carbon losses from all soils across England and Wales 1978-2003, Nature, 437, 245-248, 2005.

Bolinder, M., Andrén, O., Kätterer, T., De Jong, R., VandenBygaart, A., Angers, D., Parent, L.-E., and Gregorich, E.: Soil carbon dynamics in Canadian agricultural ecoregions: quantifying climatic influence on soil biological activity, Agriculture, Ecosys. Environ., 122, 461-470, 2007a.
Bolinder, M., Janzen, H., Gregorich, E., Angers, D., and VandenBygaart, A.: An approach for estimating net primary productivity and annual carbon inputs to soil for common agricultural crops in Canada, Agriculture, Ecosys. Environ., 118, 29-42, $2007 \mathrm{~b}$.

Bolinder, M. A., Kätterer, T., Andrén, O., Ericson, L., Parent, L. E., and Kirchmann, H.: Long-term soil organic carbon and nitrogen dynamics in forage-based crop rotations in Northern Sweden (63-64 N), Agriculture, Ecosys. Environ., 138, 335-342, 2010.

Bolinder, M. A., Kätterer, T., Andrén, O., and Parent, L. E.: Estimating carbon inputs to soil in forage-based crop rotations and modeling the effects on soil carbon dynamics in a Swedish longterm field experiment, Can. J. Soil Sci., 92, 821-833, 2012.

Cederberg, C., Flysjö, A., Sonesson, U., Sund, V., and Davis, J.: Greenhouse gas emissions from Swedish consumption of meat, milk and eggs 1990 and 2005, SIK-Institutet för livsmedel och bioteknik, 2009.

Conant, R. T., Paustian, K., and Elliott, E. T.: Grassland management and conversion into Grassland: Effects on soil carbon, Ecol. Appl., 11, 343-355, 2001.

Eriksson, J., Andersson, A., and Andersson, R.: Tillståndet i svensk åkermark (Current status of Swedish arable soils), Swedish Environmental Protection Agency, Report 4778, Stockholm, 1997.

Haberl, H., Erb, K. H., Krausmann, F., Gaube, V., Bondeau, A., Plutzar, C., Gingrich, S., Lucht, W., and Fischer-Kowalski, M.: Quantifying and mapping the human appropriation of net primary production in earth's terrestrial ecosystems, P. Natl. Acad. Sci., 104, 12942-12947, 2007.

Heikkinen, J., Ketoja, E., Nuutinen, V., and Regina, K.: Declining trend of carbon in Finnish cropland soils in 1974-2009, Glob. Change Biol., 19, 1456-1469, 2013.

Houghton, R. A., Hackler, J. L., and Lawrence, K. T.: The U.S. Carbon Budget: Contributions from Land-Use Change, Science, 285, 574-578, 1999.

IPCC: IPCC Guidelines for National Greenhouse Gas Inventories, Prepared by the National, Greenhouse Gas Inventories Programme, IGES, Japan, 2006.

Kirchmann, H., Bergström, L., Kätterer, T., Andrén, O., and Andersson, R.: Can organic crop production feed the world?, in: Organic Crop Production-Ambitions and Limitations, Springer, 39-72, 2008.

Kirchmann, H., Bergström, L., Kätterer, T., and Andersson, R.: Den ekologiska drömmen - myter och sanningar om ekologisk odling, Stockholm, Sweden, 179 pp., 2014 (in Swedish).

Kätterer, T., Andrén, O., and Jansson, P.-E.: Pedotransfer functions for estimating plant available water and bulk density in Swedish agricultural soils, Acta Agr. Scand. B-S. P., 56, 263-276, 2006.

Kätterer, T., Bolinder, M. A., Andrén, O., Kirchmann, H., and Menichetti, L.: Roots contribute more to refractory soil organic matter than above-ground crop residues, as revealed by a longterm field experiment, Agriculture, Ecosys. Environ., 141, 184 192, 2011.

Kätterer, T., Bolinder, M., Berglund, K., and Kirchmann, H.: Strategies for carbon sequestration in agricultural soils in northern Europe, Acta Agr. Scand. A-An., 62, 181-198, 2012.

Kätterer, T., Bolinder, M. A., Thorvaldsson, G., and Kirchmann, H.: Influence of ley-arable systems on soil carbon stocks in Northern Europe and Eastern Canada, in: The Role of Grasslands in a Green Future - Threats and Perspectives in Less Favoured Areas, edited by: Helgadóttir, A. and Hopkins, A., Proceedings 
of the 17th Symposium of the European Grassland Federation, Akureyri, Iceland, 23-26 June 2013, Grassland Science in Europe, 18, 47-56, 2013.

Kätterer, T., Börjesson, G., and Kirchmann, H.: Changes in organic carbon in topsoil and subsoil and microbial community composition caused by repeated additions of organic amendments and $\mathrm{N}$ fertilisation in a long-term field experiment in Sweden, Agriculture, Ecosys. Environ., 189, 110-118, 2014.

Lal, R.: Soil Carbon Sequestration Impacts on Global Climate Change and Food Security, Science, 304, 1623-1627, 2004.

Leifeld, J. and Kögel-Knabner, I.: Soil organic matter fractions as early indicators for carbon stock changes under different landuse?, Geoderma, 124, 143-155, 2005.

Leifeld, J., Angers, D. A., Chenu, C., Fuhrer, J., Kätterer, T., and Powlson, D. S.: Organic farming gives no climate change benefit through soil carbon sequestration, P. Natl. Acad. Sci., 110, E984, doi:10.1073/pnas.1220724110, 2013.

Maeder, P., Fliessbach, A., Dubois, D., Gunst, L., Fried, P., and Niggli, U.: Soil Fertility and Biodiversity in Organic Farming, Science, 296, 1694-1697, 2002.

McIntosh, P. and Allen, R.: Soil pH declines and organic carbon increases under hawkweed (Hieracium pilosella), New Zeal. J. Ecol., 17, 59-60, 1993.

Olesen, J. E., Askegaard, M., and Rasmussen, I. A.: Design of an Organic Farming Crop-Rotation Experiment, Acta Agr. Scand. B-S. P., 50, 13-21, 2000.

Poeplau, C. and Don, A.: Sensitivity of soil organic carbon stocks and fractions to different land-use changes across Europe, Geoderma, 192, 189-201, 2013.
Poeplau, C. and Don, A.: Carbon sequestration in agricultural soils via cultivation of cover crops - A meta-analysis, Agriculture, Ecosys. Environ., 200, 33-41, 2015.

Poeplau, C., Don, A., Vesterdal, L., Leifeld, J., Van Wesemael, B., Schumacher, J., and Gensior, A.: Temporal dynamics of soil organic carbon after land-use change in the temperate zone - carbon response functions as a model approach, Glob. Change Biol., 17, 2415-2427, 2011.

Rasse, D. P., Rumpel, C., and Dignac, M. F.: Is soil carbon mostly root carbon?, Mechanisms for a specific stabilisation, Plant Soil, 269, 341-356, 2005.

Reijneveld, A., van Wensem, J., and Oenema, O.: Soil organic carbon contents of agricultural land in the Netherlands between 1984 and 2004, Geoderma, 152, 231-238, 2009.

Riley, H. and Bakkegard, M.: Declines of soil organic matter content under arable cropping in southeast Norway, Acta Agr. Scand. B-S. P., 56, 217-223, 2006.

Sleutel, S., Neve, S., and Hofman, G.: Estimates of carbon stock changes in Belgian cropland, Soil Use Manage., 19, 166-171, 2003.

Smith, P., Andrén, O., Karlsson, T., Perälä, P., Regina, K., Rounsevell, M., and Van Wesemael, B.: Carbon sequestration potential in European croplands has been overestimated, Glob. Change Biol., 11, 2153-2163, 2005.

Swedish Environmental Protection Agency: National Inventory Report Sweden 2013, Stockholm, 2013. 